\title{
Breast Cancer in Middle Euphrates Region of Iraq: Risk Factors, Presenting Symptoms and Time to Medical Help-Seeking
}

\author{
Ahmed Mjali ${ }^{1}$, Safaa Ayad Jawad ${ }^{1}$, Haider Hasan Jaleel Al-Shammari²
}

${ }^{1}$ Department of Hematology /Oncology, Al- Hussein Medical City, Karbala, Iraq. ${ }^{2}$ Baghdad University, College of Medicine, Baghdad, Iraq.

\begin{abstract}
Background: Breast cancer is the most frequently occurring tumor and the first cause of death in females. Low level of understanding early symptoms leads to a late diagnosis and high mortality rates. Aims: To describe presenting symptoms, risk factors, and medical care delays among breast cancer patients in Iraq. Materials \& Methods: A retrospective, descriptive study conducted in Al-Hussein center in Karbala province of Iraq between February 2012 and August 2020. Results: There were 101 female patients with breast cancer, median age was 45 years. Most of our patients diagnosed incidentally and only $17.82 \%$ of our patients were performing breast self examination. Lack of physical activity was the most common risk factors in more than $74 \%$ of patients. Painless breast lump was the most frequent symptom in $85.14 \%$ of patients. Majority of our patients $58.42 \%$ asked medical help within six months. Limited knowledge about symptoms was the common barriers for early diagnosis in $43.94 \%$ of patients. Conclusion: Lack of knowledge about breast cancer had a major concern in our region. Increasing awareness about early symptoms and risk factors is very important for early diagnosis and proper management.
\end{abstract}

Keywords: Breast cancer- Risk factors- Symptoms- Iraq

Submission Date: 12/22/2020Ａcceptance Date: 02/14/2021
Asian Pac J Cancer Care, 6 (3), 243-247

\section{Introduction}

Worldwide, breast cancer accounting for almost 1 in 4 cancer cases among women. It is the most frequently diagnosed cancer in the vast majority of the countries [1]. In Iraq it represents more than $24 \%$ of total cancer cases making it a great challenge to the health system in our country [2].

There were several risk factors are known for breast cancer such as aging, female gender, smoking, alcohol, obesity, hormonal-replacement therapy and family history. Awareness of these factors and understanding of personal risks are essential factors for early identification, disease prevention and proper management [3-5]. Late diagnosis leads to high mortality rates among breast cancer patients, therefore researches on breast cancer prevention are performed largely around the world [6-7].

Breast self examination (BSE), screening mammography may help for early breast cancer detection [8-9]. Screening mammography for women $\geq 40$ years is approved by all major US medical organizations. It is

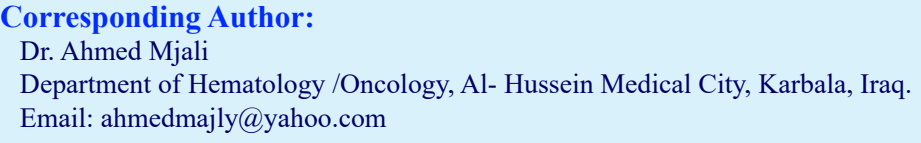

decrease mortality from breast cancer by about $20 \%-35 \%$ in women aged 50 to 69 years. In young age with high risk magnetic resonance imaging and ultrasound are being tested, but are not approved for screening the general population [10].

In this study, we investigated breast cancer risk factors, most common presenting symptoms and barriers of early diagnosis among Iraqi patients. It can help to provide basic information and to develop future treatment strategies in our country.

\section{Materials and Methods}

This a retrospective, descriptive study conducted in Al-Hussein cancer center in Karbala province of Iraq on breast cancer patients during period from February 2012 and August 2020. This center was established in November 2011 with oncology \& hematology wards. It covers not only Karbala population but other patients 
from Middle Euphrates region of Iraq are referred to this center for solid \& hematological malignancy treatment [11-12]. We selected 101 female breast cancer patients, they were asked directly and all the information were recorded through their regular visits to our center.

The questionnaire included: Section A, section B and section C. Section A dealt with socio-demographic details including: Age, marital status, number of pregnancies, family history, level of education and family income. Regarding income, we divided our patients into: low monthly income less than 500,000 Iraqi Dinars (IQD), middle monthly income within 500,000 - 1,000,000 IQD and high income over 1,000,000 IQD per month [13].

In Section B, the questions were on presenting symptoms, stage, barriers and duration for seeking medical help. In section $\mathrm{C}$, the questions raised about risk factors for breast cancer in our patients.

Patients with non-conclusive results were excluded from this study. Collected information was kept confidential. This study was approved by review ethical committee of Karbala teaching hospital, Iraq.

\section{Results}

\section{Socio-demographic data}

There were 101 women enrolled in our study. Median age was 45 years, range was (25-70) years. Majority of our patients were married in 91 patients $(90.09 \%)$ and 35 patients $(34.65 \%)$ were illiterates. Only 13 patients $(12.87 \%)$ had family history of breast cancer. Other data are explained in (Table 1).

Most of our patients $74.26 \%$ diagnosed incidentally after developing symptoms, while $17.82 \%$ performed BSE and only $7.92 \%$ had opportunity to screening mammography (Figure 1).

\section{Risk factors}

The most common risk factors for breast cancer in our patients were: Lack of physical activity in 75 patients $(74.26 \%)$ followed by breastfeeding ( $<6$ months) in 31 patients $(30.69 \%)$, low vegetable intake $(<3$ times per week) in 27 patients $(26.73 \%)$, obesity in 26 patients (25.74\%), high fat diet ( $>3$ times per week) in 24 patients $(23.76 \%)$, oral contraceptive use in 21 patients

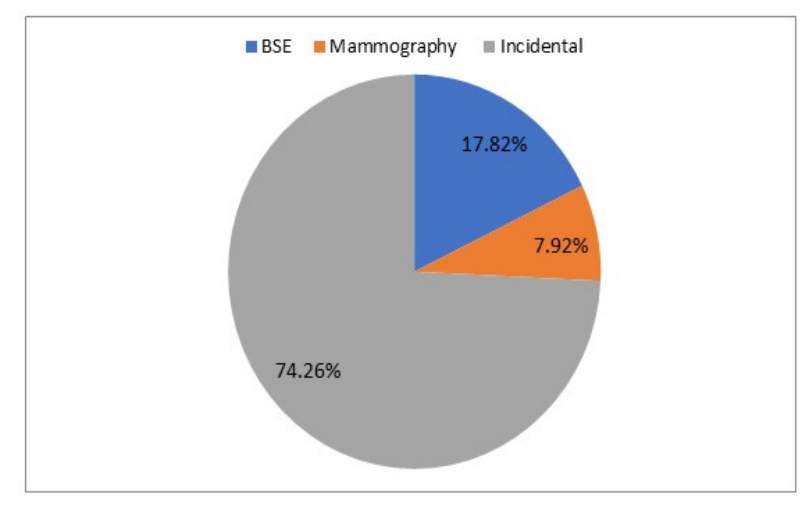

Figure 1. The Distribution of Different Procedures of Early Detection among Studied Subjects
Table 1. Socio-demographic Variables of 101 Patients

\begin{tabular}{|c|c|}
\hline Variable & Number (Percent) \\
\hline \multicolumn{2}{|l|}{ Age in years } \\
\hline $20-30$ & $7(6.93)$ \\
\hline $31-40$ & $24(23.76)$ \\
\hline $41-50$ & $41(40.60)$ \\
\hline $51-60$ & $21(20.79)$ \\
\hline$>60$ & $8(7.92)$ \\
\hline \multicolumn{2}{|l|}{ Marital status } \\
\hline Single & $4(3.96)$ \\
\hline Married & $91(90.10)$ \\
\hline Divorced & $1(0.99)$ \\
\hline Widowed & $5(4.95)$ \\
\hline \multicolumn{2}{|l|}{ Education } \\
\hline Illiterate & $35(34.65)$ \\
\hline Primary school & $12(11.89)$ \\
\hline Secondary school & $16(15.84)$ \\
\hline Higher education & $38(37.62)$ \\
\hline \multicolumn{2}{|l|}{ Occupation } \\
\hline Employed & $26(25.75)$ \\
\hline Unemployed & $75(74.25)$ \\
\hline \multicolumn{2}{|l|}{ Family income } \\
\hline Low & $32(31.68)$ \\
\hline Middle & $56(55.44)$ \\
\hline High & $13(12.88)$ \\
\hline \multicolumn{2}{|l|}{ Number of pregnancies } \\
\hline 0 & $6(5.94)$ \\
\hline 1 & $6(5.94)$ \\
\hline $2-4$ & $48(47.52)$ \\
\hline$>4$ & $41(40.60)$ \\
\hline \multicolumn{2}{|c|}{ Family history of breast cancer } \\
\hline Yes & $13(12.87)$ \\
\hline No & $88(87.13)$ \\
\hline
\end{tabular}

(20.79\%), nulli para in 6 patients (5.94\%), using hormone replacement therapy in 4 patients $(3.96 \%)$, early onset of menses (before the age of 12 years) in 4 patients (3.96\%), smoking in 3 patients $(2.97 \%)$, late menopause (after the age of 55 years) in 3 patients $(2.97 \%)$ and high-dose radiation to chest in 2 patients $(1.98 \%)$ as shown in (Figure 2).

\section{Breast cancer symptoms}

Most frequent symptom was painless breast lump in 86 patients $(85.14 \%)$ followed by lump under armpit in 36 patients $(35.65 \%)$, breast asymmetry in 24 patients (23.77\%), nipple retraction in 19 patients $(18.82 \%)$, change in breast shape in 18 patients $(17.82 \%)$, dimpling of breast skin in 15 patients $(14.86 \%)$, breast pain in 10 patients (9.90\%), nipple discharge in 7 patients (6.94\%) and bloody discharge in 4 patients $(3.97 \%)$ as shown in (Table 2$)$. 


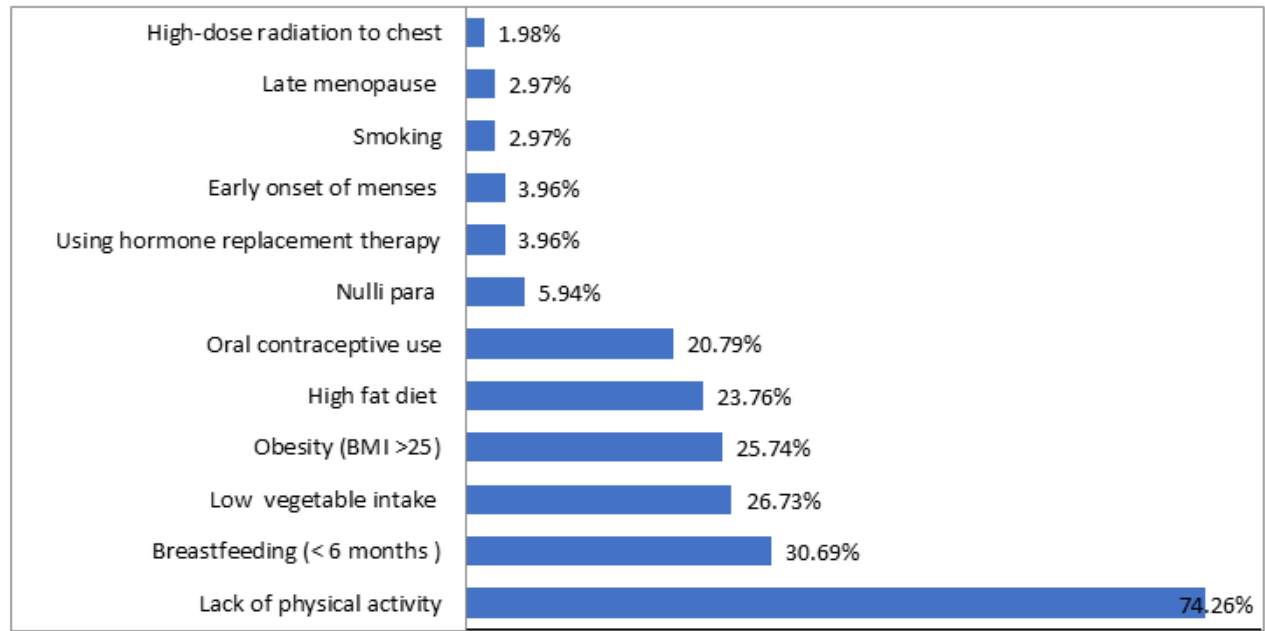

Figure 2. Distribution of Different Known Risk Factors among Our Breast Cancer Patients

\section{Presenting stages}

The most common presenting stage in our patients was stage III in 40 patients $(39.60 \%)$ followed by stage II in 32 patients $(31.68 \%)$, stage IV in 22 patients $(21.78 \%)$ and stage $\mathrm{I}$ in 7 patients $(6.93 \%)$ as shown in (Figure 3 ).

\section{Time to reach final diagnosis}

Most of our patients asked medical help within 1 - 6 months in 59 patients $(58.42 \%)$ while 35 patients (34.65\%) diagnosed within 1 month, 6 patients $(5.94 \%)$ diagnosed within $7-12$ months and 1 patient $(0.99 \%)$ diagnosed after one year (Table 3).

\section{Barriers for early diagnosis}

The most common barrier for urgent medical help was

Table 2. Distribution of Different Presenting Symptom in Our Patients

\begin{tabular}{lc}
\hline Variable & Nuimber (Percent) \\
\hline Painless breast lump & $86(85.14)$ \\
Lump under armpit & $36(35.65)$ \\
Breast asymmetry & $24(23.77)$ \\
Nipple retraction & $19(18.82)$ \\
Change in breast shape & $18(17.82)$ \\
Dimpling of breast skin & $15(14.86)$ \\
Breast pain & $10(9.90)$ \\
Nipple discharge & $7(6.94)$ \\
Bloody discharge & $4(3.97)$ \\
\hline
\end{tabular}

Table 3. Distribution of Patients Delays in Seeking Care among the Studied Populations. Time from Symptoms to Diagnosis.

\begin{tabular}{lc}
\hline Time & Number (Percent) \\
\hline$<1$ month & $35(34.65)$ \\
1 month -6 months & $59(58.42)$ \\
7 months -12 months & $6(5.94)$ \\
$>12$ months & $1(0.99)$ \\
Total & $101(100)$ \\
\hline
\end{tabular}

limited knowledge about symptoms in $43.94 \%$ followed by neglect in $39.39 \%$, fear in $12.12 \%$ and not having doctor nearby in $4.54 \%$ as shown in (Figure 4 ).

\section{Discussion}

Cancer patients tend to present with heterogonous presentations and complications making treatment of those patients as a serious issue. Detection of the disease in its early stages before the appearance of signs \& symptoms improve outcomes dramatically [14-20]. This study was carried out to understand risk factors, presenting symptoms and barriers to urgent medical help among breast cancer patients in Middle Euphrates region of Iraq.

Median age in our study was 45 years, this younger than median age in other parts of Iraq (49 years), Turkey (51 years) and US (62 years) this may be explained by our small sample size and short follow- up period [21-23].

Majority of our patients diagnosed incidentally, $17.82 \%$ performed BSE and only $7.92 \%$ performed screening mammography. Same results from Africa where majority of patients diagnosed incidentally after symptoms development. Unfortunately, our screening results revealed low compliance comparing to previous studies in other parts of Iraq, US, Saudi Arabia, Turkey

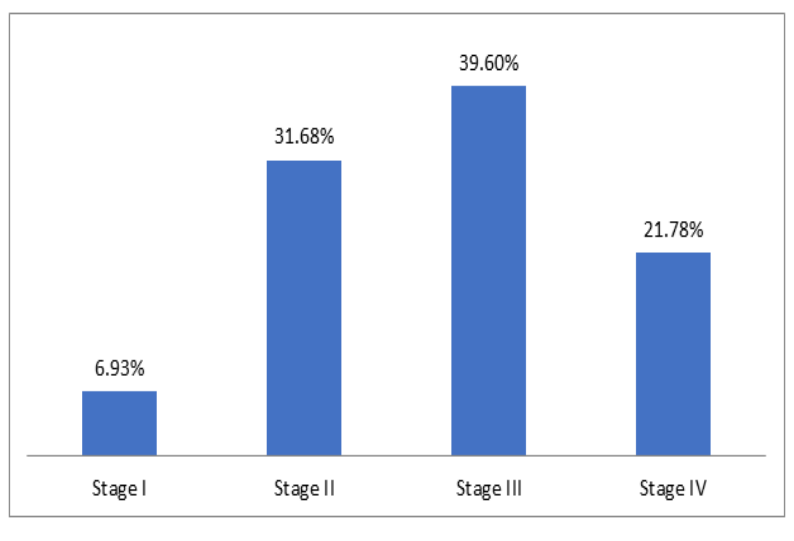

Figure 3. Distribution of Presenting Stages among Studied Population 


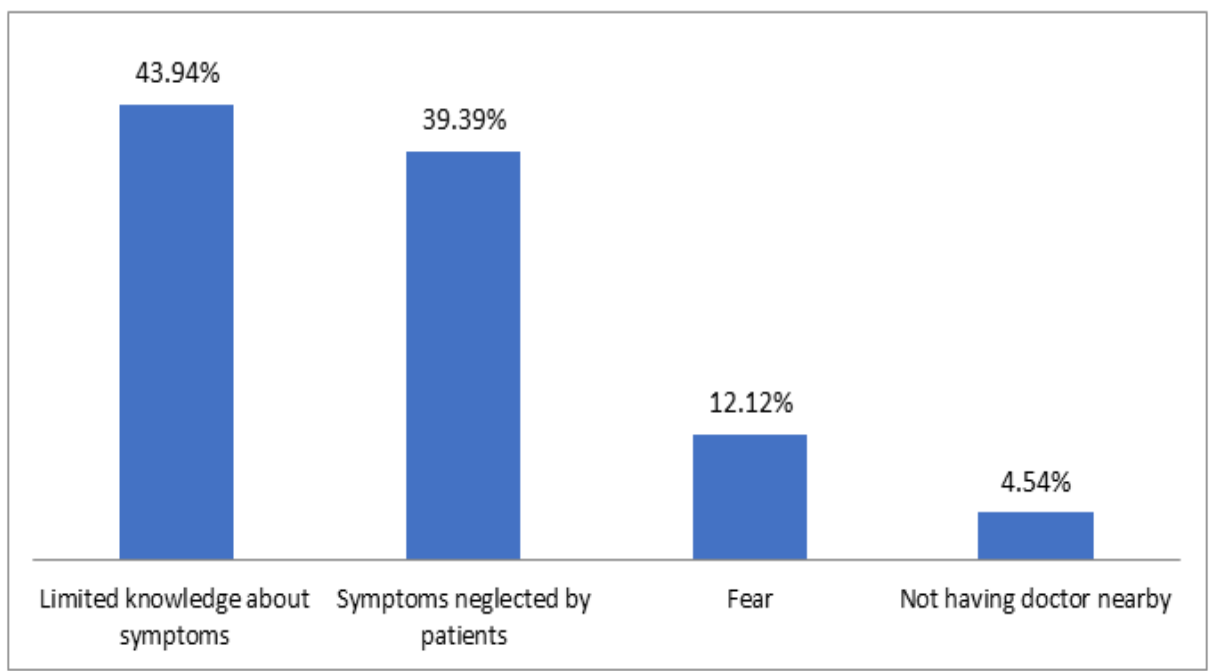

Figure 4. Frequency of Different Barriers for Early Diagnosis

and Iran [24-30].

Unhealthy life style was the main risk factor in our patients same results among Indian and Jordanian women [31-32]. But in Europe the use of hormone therapy, older age at the first birth and smoking were common risk factors [33]. On other hand about $12.8 \%$ of our patients had family history of breast cancer. This lower than previous studies in Iraq (18.7\%) Turkey (15.8\%) but it is higher than in India (4.2\%) [22,34-35].

Breast painless lump was the most reported symptom among our patients, same results in previous studies in Iraq, India, Turkey and UK $[22,34,36]$. Our patients tend to present in late stages, this was agreed with results in previous studies in Iraq and Africa where most of patients presented in advance stages. However, European women are more likely to present when the disease is still in its early stages [37-38].

Most of our patients asked medical help within six months after observing symptoms. This is longer than time in neighboring and high-income countries where the median time for medical consultation was 7-16 days only [39-40]. The most frequent barrier for early diagnosis in our study was limited knowledge about symptoms and neglect which is same in neighboring and African countries $[26,40]$.

In conclusion, most of our patients diagnosed incidentally after appearance of symptoms. Unhealthy life style was the most common risk factor and breast lump was the most frequent symptom. Our patient tends to present in advance stages and majority of them wait 1-6 months before final diagnosis. Limited knowledge about symptoms and neglect were the main barriers for early diagnosis. Our findings show the need for community awareness and education programs about breast cancer signs, symptoms and treatment options among Iraqi women.

\section{References}

1. Bray F, Ferlay J, Soerjomataram I, Siegel RL, Torre LA, Jemal A. Global cancer statistics 2018: GLOBOCAN estimates of incidence and mortality worldwide for 36 cancers in 185 countries. CA: A Cancer Journal for Clinicians. 2018 09 12;68(6):394-424. https://doi.org/10.3322/caac.21492

2. Mjali A, Najeh Hasan Al Baroodi B. Some Facts About Cancers in Karbala province of Iraq, 2012-2020. Asian Pacific Journal of Cancer Care. 202006 07;5(2):67-69. https://doi.org/10.31557/apjcc.2020.5.2.67-69

3. Allam M, Abd Elaziz K. Evaluation of the level of knowledge of Egyptian women of breast cancer and its risk factors.A cross sectional study. Journal of Preventive Medicine and Hygiene. 2012 Dec 04; Vol 53:No 4 (2012). https://doi. org/10.15167/2421-4248/JPMH2012.53.4.347

4. Kurtuncu M, Akhan LU, Celik S, Alkan I. Cancer Awareness among University Students in Turkey. Asian Pacific Journal of Cancer Prevention. 201405 30;15(10):4289-4294. https:// doi.org/10.7314/apjcp.2014.15.10.4289

5. Mjali A, Sheikha A, Amin HA, Al-Anssari MJ, Aljawdah ZDA, Abbas SK. Association between Female Breast Cancer and Different ABO Blood Groups \& Rh Factor in the Sulaymaniyah Province of Iraqi Kurdistan. Indian Journal of Public Health Research \& Development. 2019;10(6):454. https://doi.org/10.5958/0976-5506.2019.01315.9

6. Celik S, Tasdemir N, Sancak H, Demirel M, Akman O, Kara M. Breast Cancer Awareness among Turkish Nursing Students. Asian Pacific Journal of Cancer Prevention. 2014 Nov 06;15(20):8941-8946. https://doi.org/10.7314/ apjcp.2014.15.20.8941

7. Gupta A, Shridhar K, Dhillon P. A review of breast cancer awareness among women in India: Cancer literate or awareness deficit?. European Journal of Cancer. 2015 09;51(14):2058-2066. https://doi.org/10.1016/j. ejca.2015.07.008

8. Suleiman A. Awareness and attitudes regarding breast cancer and breast self-examination among female Jordanian students. Journal of Basic and Clinical Pharmacy. 2014;5(3):74. https://doi.org/10.4103/0976-0105.139730

9. Levshin V, Fedichkina T, Droggachih V. The experience of breast cancer screening. Eur J Cancer. 1998;34(1005):S95.

10. Elmore JG. Screening for Breast Cancer. JAMA. 200503 09;293(10):1245. https://doi.org/10.1001/jama.293.10.1245

11. Mjali A, Jawad SA, Al Baroodi BNH. Gynecological Cancer 
in Middle Euphrates Region of Iraq, 2012-2020. Asian Pacific Journal of Environment and Cancer. 2020 06 04;3(1):17-18. https://doi.org/10.31557/apjec.2020.3.1.17-18

12. Mjali A, Abbas S. Imatinib Mesylate Adherence in Chronic Myeloid Leukemia Patients: Data from Middle Euphrates Region of Iraq. Sys Rev Pharm. 2021 Jan;12(1):83-7.

13. United Nation Publication Fund-Iraq. Demographic Survey, Kurdistan Region of Iraq. 2018 [cited 2020 July 2]. Available from: https://iraq.iom.int/files/KRSO IOM UNFPA Demographic_Survey_Kurdistan_Region_of_Iraq.pdf.

14. Mjali A, Kareem Y, Al-Shammari H, et al. Chronic myeloid leukemia patient with isolated central nervous system blast crisis. World J Pharm Pharm Sci. 2019;8(9):111-7. https:// doi.org/10.20959/wjpps20199-14651

15. Mjali A, Hasan D, Al-Anssari M, et al. Myeloid sarcoma as the presenting symptom of chronic myeloid leukemia chronic phase: A case report. World J Pharm Res. 2017;6(13):10-5.

16. Mjali A, Kehiosh H, Al-Ansari M, et al. Primary Cutaneous Aspergillosis in Acute Myeloid Leukemia Patient: A Case Report. World J Pharm Res. 2017;6(15):105-11.

17. Mjali A, Al Baroodi B, Al-Shammari H, et al. Skin Reaction at Site of Intrathecal Methotrexate. World J Pharm Res. 2019;8(10):170-3. https://doi.org/10.20959/wjpr20191015723

18. Mjali A, Abbas S, Mutlag J, et al. Acute Promyelocytic Leukemia in Third Trimester Pregnant Women Treated with All-Trans-Retinoic Acid. World J Pharm Pharm Sci. 2019;8(9):146-51.

19. Mjali A, Al-Anssari M, Al-Shammari H. Vincristine Induced Vocal Cord Paralysis in Patient with Diffuse Large B-cell Lymphoma: A Case Report. World J Pharm Res. 2017;6(12):11-5.

20. Mjali A, Alshami M, Metib N, et al. Proliferating Trichilemmal Tumor: Case Report. Karbala J Med. 2017;10(2):2800-3.

21. AL-Hashimi MMY, Wang XJ. Breast Cancer in Iraq, Incidence Trends from 2000-2009. Asian Pacific Journal of Cancer Prevention. 201401 15;15(1):281-286. https://doi. org/10.7314/apjcp.2014.15.1.281

22. Ozmen V, Ozmen T, Dogru V. Breast Cancer in Turkey; An Analysis of 20.000 Patients with Breast Cancer. European Journal of Breast Healt. 201907 02;15(3):141-146. https:// doi.org/10.5152/ejbh.2019.4890

23. Siegel RL, Miller KD, Jemal A. Cancer statistics, 2016. CA: A Cancer Journal for Clinicians. 2016 01;66(1):7-30. https:// doi.org/10.3322/caac.21332

24. Roth MY, Elmore JG, Yi-Frazier JP, Reisch LM, Oster NV, Miglioretti DL. Self-Detection Remains a Key Method of Breast Cancer Detection for U.S. Women. Journal of Women's Health. 2011 08;20(8):1135-1139. https://doi. org/10.1089/jwh.2010.2493

25. Ozmen V. Breast cancer in the world and Turkey. J Breast Health. 2008 Apr;4(2):6-12.

26. Getachew S, Tesfaw A, Kaba M, Wienke A, Taylor L, Kantelhardt EJ, Addissie A. Perceived barriers to early diagnosis of breast Cancer in south and southwestern Ethiopia: a qualitative study. BMC Women's Health. 2020 02 27;20(1). https://doi.org/10.1186/s12905-020-00909-7

27. Bakr R, AL-Mulhim F, Almedallah D, Alkaltham N, Alotaibi A, Alnoaim S. Screening mammography and breast selfexamination: Attitudes and practices of women in the Eastern Province of Saudi Arabia. Saudi Journal for Health Sciences. 2018;7(2):89. https://doi.org/10.4103/sjhs.sjhs_4_18

28. Karayurt Ö, Özmen D, Çetinkaya AÇ. Awareness of breast cancer risk factors and practice of breast self examination among high school students in Turkey. BMC Public Health.
2008 Oct 17;8(1). https://doi.org/10.1186/1471-2458-8-359

29. Jahan S, Al-Saigul A, Abdelgadir M. Breast cancer. Knowledge, attitudes and practices of breast self examination among women in Qassim region of Saudi Arabia. Saudi Med J. 2006;27(11):1737-41.

30. Montazeri A, Vahdaninia M, Harirchi I, Harirchi A, Sajadian A, Khaleghi F, Ebrahimi M, Haghighat S, Jarvandi S. Breast cancer in Iran: need for greater women awareness of warning signs and effective screening methods. Asia Pacific Family Medicine. 2008;7(1):6. https://doi.org/10.1186/1447056x-7-6

31. Antony M, Surakutty B, Vasu T, et al. Risk factors for breast cancer among Indian women: A case-control study. Niger J Clin Pract. 2018 Apr 6;21(4). https://doi.org/10.4103/njcp. njcp_102_17

32. Al Qadire M, Alkhalaileh M. Risk factors for breast Cancer among Jordanian women: a case-control study. Iran J Public Health. 2018 Jan;47(1):49.

33. Aljohar BA, Kilani MA. Breast Cancer in Europe: Epidemiology, Risk Factors, Policies and Strategies. A Literature Review. Global Journal of Health Science. 2018 Oct 13;10(11):1. https://doi.org/10.5539/gjhs.v10n11p1

34. Alwan N, Tawfeeq F, Mallah N. Demographic and clinical profiles of female patients diagnosed with breast cancer in Iraq. J Contemp Med Sci. 2019 Mar 4;5(1):14-9.

35. Velappan A, Shumugam D. Analysis of Demographic Characteristics and Treatment Outcome of Breast Cancer Patients in a Tertiary Cancer Centre. IOSR Journal of Dental and Medical Sciences. 2017 05;16(05):25-28. https://doi. org/10.9790/0853-1605092528

36. Koo MM, von Wagner C, Abel GA, McPhail S, Rubin GP, Lyratzopoulos G. Typical and atypical presenting symptoms of breast cancer and their associations with diagnostic intervals: Evidence from a national audit of cancer diagnosis. Cancer Epidemiology. 2017 06;48:140-146. https://doi. org/10.1016/j.canep.2017.04.010

37. Mutar MT, Goyani MS, Had AM, Mahmood AS. Pattern of Presentation of Patients With Breast Cancer in Iraq in 2018: A Cross-Sectional Study. Journal of Global Oncology. 2019 Dec;(5):1-6. https://doi.org/10.1200/jgo.19.00041

38. Abdulrahman GO, Rahman GA. Epidemiology of Breast Cancer in Europe and Africa. Journal of Cancer Epidemiology. 2012;2012:1-5. https://doi.org/10.1155/2012/915610

39. Abdel-Razeq H, Mansour A, Jaddan D. Breast Cancer Care in Jordan. JCO Global Oncology. 2020 Nov;(6):260-268. https://doi.org/10.1200/jgo.19.00279

40. Ahmad Abu-Helalah M, Alshraideh AH, Al-Hanaqtah M, Da'na M, Al-Omari A, Mubaidin R. Delay in Presentation, Diagnosis, and Treatment for Breast Cancer Patients in Jordan. The Breast Journal. 2015 Dec 14;22(2):213-217. https://doi.org/10.1111/tbj.12541

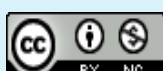

This work is licensed under a Creative Commons AttributionNon Commercial 4.0 International License. 